TRAMES, 2008, 12(62/57), 3, 264-275

\title{
MEMORY, ANACHRONISM, AND ARTICULATION
}

\section{Seppo Knuuttila}

\author{
University of Joensuu
}

\begin{abstract}
This article examines examples of time travel in folklore and science fiction. The aim is to emphasize that the subject of remembering could be both experienced and fictional. Memory and imagination produce and affirm together the actual meanings about the past. This kind of past and present articulation is one of the most relevant research subjects in contemporary folklore studies. The combination of memory and narration is always anachronistic in the sense that we are able to remember and tell how the future will come true in the past. The so-called anachronism debate of recent decades has been concerned with argumentation in academic texts. From the folkloristic point of view it would provide space for new interpretations, the anachronisms were seen as a special figure of speech and narrative.
\end{abstract}

DOI: $10.3176 /$ tr.2008.3.02

Keywords: anachronism, memory, imagination, time travel, trope, articulation

\section{Introduction}

The first issue I am concerned with in this paper is how the articulation of memory and imagination makes it possible to move in time. Initially, I describe some rules and paradoxes of time-travel as they have been depicted in folklore and science fiction. In this context anachronisms are like vehicles and channels to timelessness or a place outside time, to a mythic history, mythscape. In folklore studies myths are usually understood as both imagined and remembered texts, as Barbara A. Misztal writes: "Memory is crucial to our ability to sustain a continuity of experience, while our imaginative thinking is based on our ability to make the world intelligible and meaningful" (2003:119).

The second issue concerns the prohibitions and regulations of anachronisms related to historiological methodology, in the old and new historicism. In the world of research simple anachronisms are of course errors and mistakes, but on the other hand, what in one context is a mistake, can in another be the correct 
interpretation if not a simple truth. It is said that logically taken the articulation of the old historicism and the rules against anachronisms are a kind of science fiction or time travelling as such. The anachronism debate has sometimes been a touchstone of interdisciplinarity as well.

The third aspect of this presentation concerns the use of anachronism. Because time-travel is so popular a theme in folklore, literature and popular culture, it demands a more complicated interpretation than the faults hypothesis. It would be productive to see anachronism and its family resemblance terms as a trope or on the specific level, as a temporal speech figure, in which case it would be parallel to such major tropes as metaphor, metonym and irony and also to other, more vague figures of speech.

\section{The folkloristic perspective}

My academic background is in folkloristics, and has been for over thirty years, so that I would like to make some folkloristic distinctions concerning the concept of memory. Folklorists normally use the term memory in connection with some other term. Briefly, for us, memory is always articulated through a text, even in the contextual and performance-centred approaches. For folklorists the text has been the most important research subject and object, full of meanings even without context. This is quite far from the anthropological statement written by Gregory Bateson (1980:24): "Without context, words and actions have no meaning at all." This broad interpretation of a text with complicated articulations stems - partly, at least - from the cultural semiotic school, which has its roots in Tartu.

From the Estonian perspective, Tiiu Jaago, Ene Kõresaar and Aigi Rahi-Tamm have written, that "oral history in Estonian folkloristics is primarily characterised by the question of how folklore texts describe the mutual relations of the continuity and the changing of Estonian society and culture" (Jaago et al., 2006:6). They believe that one of the central research problems is why and how people from the same region, or more generally, the people of Estonia, see and describe the same events in a different way. Bernhard Giesen, a sociologist, claims that "differences between collective memories are as normal as differences between individual memories are" (Giesen 2004:32). For him the central problem is rather: "Under which conditions does this division become a problem and - above all why do different individuals merge their memories to form a collective memory of a generation?" So, the questions differ from time to time and from discipline to discipline.

By definition folklore is traditional, a shared verbal representation, which reflects and recreates worldviews and mentalities. For the earlier generations of folklorists, memory, or shall we say remembrance, was not the central problem, because according to their opinions and interpretations the folklore process followed the so-called laws of cultural models (evolution/devolution, etc.). Those law constructions included all kinds of sub-laws, for instance, laws of diffusion, 
transmission, epic, meter and memory. The purpose of the last-mentioned laws was to explain, why and how folklore is changing from one generation to another. The question of transmitting folklore was more important than remembering. Nowadays it is more relevant to ask how memories and their expressions are articulated in social, historical, physical and emotional contexts.

In the history of folkloristics, multidisciplinary activities have by nature been quite practical. This means that in addition to folklorists, students of literature, history, religion, anthropology, psychology, geography and so on, have had a common research subject, for instance, myth, but each of them has sketched out the subject from their own disciplinary perspective. Even in the area of folklore studies, we can find many books written using this multidisciplinary prescription.

Let's take another perspective. In his article Multidisciplinarity, interdisciplinarity, and patterns of research collaboration in nanoscience and nanotechnology Joachim Shummer sees disciplinary relations in the following way: "Thus, a research field can be highly multidisciplinary without being interdisciplinary, if many disciplines are participating without any interaction between them. Similarly, strong interdisciplinary research between only two disciplines does not mean a high degree of multidisciplinarity" (Shummer 2004:444).

\section{Imagination in time}

There is a riddle that asks, what is the quickest way from one place to another? The correct answer is the imagination, and it applies well to the riddle of travelling in time. Anachronism is one way of doing this. It functions excellently in the contexts of creative work and appears diversely in all art forms. Thus it is a fundamentally different matter how we want to express travel in time by using anachronisms, and why they need to be avoided, especially in a historiological conclusion.

In science fiction that depicts time travel to the past, there are many different ways to express the rule that a person travelling in the past may do nothing to affect it. Nor can anything be done that would change those beings, conditions and events which exist and function in that time. This rule is, however, speculative and has produced numerous paradoxes. Some of the versions resulting from this are known as the 'time paradox/causal loop', 'predestination paradox', 'grandfather paradox'. For example, in the Motif-index of Folk-Literature by Stith Thompson $(1932,1989)$ we can easily find numerous motifs around the time paradox ('Supernatural lapse of time in fairyland', 'A year seemed like a few hours', 'Magic sleep extending over many years', 'Snow White', 'Sleeping Beauty', etc.).

In the Ray Bradbury story A Sound of Thunder (1952) a group of men travel six million years back in time to hunt dinosaurs. The text has many logical, even comic, ruptures, but stated briefly its message is this: since one of the travellers 
broke the stated rule by accidentally stepping on a butterfly, upon their return to the present they find that language has degenerated and the fascist candidate Deutscher has won the presidential election.

The time-travel rule somewhat resembles the promises and prohibitions of myths and fairy tales: everything is permitted but do not eat from this tree, do not open this box, do not enter that room, do not interfere in the course of events regardless of what you see or what might happen. On the other hand, these texts would not exist if the rules were not broken.

Boris Kuznetsov, in turn, explains in his A Journey through the Ages (1980) how the time machine was designed to specifically protect against changes "which could have caused a chain reaction and led to unforeseen consequences". The novel's narrator refers intertextually to this possibility as the 'Bradbury effect'. In the novel's fictive discussions between philosophers and artists of different eras, however, the narrator does not shrink from expressing questions about the future. He asks Plato and Descartes what they think of his coming from the future in a time machine. In this way, Kuznetsov in his fiction - clearly and intentionally breaks those rules of anachronism, which I will next discuss.

The above fragments are examples of imagination and texts you have perhaps read or seen and can remember. For folklorists today the most important question is not whether the stories are fiction or not. Much more interesting is how the articulations of imagination and memory work, and asking why time travel has been such a productive motif in the popular imagination for millennia.

\section{Demands to avoid anachronisms}

How can we understand the ideas of people of the past without transforming them into those similar to our own? These two issues (to understand and be unchanged) have been central, for example in research concerning popular worldviews and mentalities. We cannot, without fateful consequences, divorce ourselves from the narratives of the past, nor physically return to the past to better them.

The rules and prohibitions concerning the time perspective were present throughout the entire 20th century in the broad discussion on representing history. The central thread of historicism has been that the researcher should put their soul into the period the research concerns. The demand is simply that the researcher does not transfer anything from the present to the past but that they only 'shut down' and let the 'sources speak'. According to this doctrine the researcher organizes events in the correct chronological order, thus establishing a causeeffect relationship. Although this demand has often proven impossible, historicism still has its defenders, especially in popular presentations. And when more and more supporters appear, the demands to avoid anachronism also require new interpretations.

Of the rigid voices to prohibit anachronism, perhaps the most fervent discussion has been aroused by Quentin Skinner, who wrote that "the relevant 
logical consideration is that no agent can eventually be said to have meant or done something which he could never be brought to accept as a correct description of what he had meant or done" (Skinner 1989:48).

Skinner wrote that we should not 'find' contemporary ideas in past ages, nor express ideas in someone's name which they perhaps "could have been conscious of" (Ibid. 33). Skinner also rejects such conceptual history in which actors in various periods are said to have employed the same concept - for instance, art although in different contexts. In all these and in other cases as well anachronism is simply an error in drawing conclusions, which is fatal to any study. In the Skinnerian vocabulary anachronism compares with myth, which historians should also avoid.

According to Richard Rorty's interpretation the constraint demanded by Skinner specifically affects the method of historical reconstruction, which attempts to analyse the authentic meaning of a text in its historical contexts. Rorty states that the task of rational reconstruction and intellectual history is in contrast to interpreting the philosophical (history of learning) significance of the text in relation to our own times, and thus the reconstruction of the historical meaning is dependent on the interpreter. Literally taken this means that the old historicism is methodologically unthinkable: If we could turn off our present consciousness, then we can no longer remember what we are going to do (Rorty 1984:54-55).

The New Historicism, especially active in literary studies at the end of the last century, was not a method in the first place but rather a research programme or agenda seeking to substitute the synchronic text of a cultural system for the diachronic text of an autonomous literary history (Rée 1991:978-980). Such a programme sounds like the history of mentalities concerning different eras (mentality of the Middle Ages, mentality of the Renaissance, etc.).

If anachronisms are, however, understood in a broader sense than just incorrect conclusions, then many of those participating in the debate today also believe that the past in many ways goes with us into the present, and that the present can also be understood in terms other than the period that limits our experience. Nick Jardine ends his critical review of anachronism with the thought that the "use of categories alien to the agents studied is often perfectly legitimate" (2000:265). It has been said that historical events can clearly be understood from a latter-day perspective, when the interpreter comprehends what they are doing. On the other hand, there is also a desire to simplify Skinner's thesis in the sense that the researcher should not claim that some person (actor) in the past said (did) something, which they did not.

One of the ethical reasons for avoiding anachronisms in historical research is to insure that people and things as the subject of interest are approached in a fair way. According to the Finnish historian Jorma Kalela (2000) this 'fair way' thesis contains two problems. The first concerns the historian's own concept of reality and language, which are not neutral in respect to depicting fairness. The second is that the culture as the research subject is not transparent, although we generally so 
assume. Kalela believes that satisfaction with avoiding anachronisms has actually hidden the bulk of difficulties related to historical reconstruction.

Kalela writes of unintentional anachronisms which, when we think about time, are commonly considered to be uncomplicated or linear. He presents this example: "a structural feature of Gustaf Vasa's (King of Sweden from 1523 until his death in 1560) personality was that he was unable in his thoughts to separate his position as ruler from his being a private individual". The word 'unable' in this sentence, Kalela remarks, is an unintentional anachronism since it is clearly a modern way of portraying the personality trait in question: "For people living in the culture of Gustaf Vasa the idea behind this expression separating the position of the ruler and the private individual would probably have been alien" (Kalela, 2000:104). On the other hand, we could also think that unintentional anachronisms are not necessary to be taken literally, but rather as temporal tropes. Thus, the expression "was unable" would mean precisely the contemporary viewpoint at the time of its writing.

Let me briefly add that the way of reading can also be anachronistic, by design or unintentionally. In this way, for example, Renato Rosaldo (1986) has read Emmanuel Le Roy Ladurie's (1975) book Montaillou (Cathars and Catholics in a French Village 1294-1324,). Le Roy Ladurie, "a noted French social historian ... cloaks himself with the borrowed authority of ethnographic science" (Rosaldo, 1986:81). Rosaldo writes rigorously against Ladurie's self-made ethnography, which at least "tempts the historian into committing his discipline's cardinal sin: anachronism" (Ibid. 83). The examples are not in my opinion so upsettingly sinful, and it now seems, twenty years later, that also Rosaldo's reading strategy was anachronistically oriented, although he has made many sharp and apt remarks.

The debate on anachronisms and their erroneousness in the philosophy of history and science circles has primarily produced grounds for why the present should not be projected onto the past, and what would occur if this rule was broken. Perhaps more, however, has come from the debate that considers the various manifestations of anachronisms and their recognition. This discussion has specifically been useful in such cultural studies which are interested in the intentional use of anachronisms, for example, for critical, humorous and didactic, or life philosophical purposes. Anachronisms are particularly part of everyday popular culture.

\section{Anachronism as a trope}

The way I use the term trope in this article has almost nothing to do with the philosophical trope theories, in which the key concepts are universal, particulars, properties and qualities. My interdisciplinary trope attitude is directed towards literary studies and anthropological use, that is 'the poetry of language and speech'. 
There are innumerable differing interpretations and definitions of the rhetoric of tropes as forms of expression and figures of speech. Four main tropes (metaphor, metonym, synecdoche and irony) are commonly noted, but according to a count of terms in interdisciplinary source materials the number of tropes, including all their differentiations, comes to more than 50. Moreover, this estimate does not yet include anachronism, which I propose to add to this group, as a trope. Stated briefly, trope in this sense means an articulation in which two (or more) utterances combine to form a so-called third meaning. Anachronism differs from the main tropes in that it always manipulates the course and structures of time.

There are some proposals to distinguish temporal, categorical and placebounded tropes from each other in the following way:

Interpretative anachronism applies categories originating in one culture or society to deeds or works in a culture in which these categories are alien. We may call this mode of interpretation 'anatropism', exploiting the fact that the ancient Greek tropos could be applied to social and cultural orientation as well as to physical direction (Jardine 2000:253).

Just as we have a term for thinking about things in the wrong time anachronism - we might invent a term for things in the wrong place - anachorism (Cresswell 2004:103).

However, if we accept that memory and narration in action form an articulation, then we have to accept the theory of cultural constructivism, which methodologically is based on the idea of articulation, and vice versa. All the interpretations of memory and narration stress their contextual and constructive relations. The core area of current cultural research has been the study of various systems and constructions of meaning; in the course of a quarter-century this has in particular been built on articulation theory and its numerous models, which highlight societal activity and politics. By definition, articulation involves the creation, breakdown and reproduction of practices of meaning. From its standpoint narrative texts are related to contexts of memory and the linked texts and contexts are further connected to cultural practices. Barbara A. Misztal writes: "Because memory is a field of the articulation of public and private interests, values and aspirations, it is also the site where contradictions of identities are often contested" (2003:120).

The lack of articulation can also be informative. In connection to not telling or not remembering I would like to briefly refer to anthropologist Gregory Bateson's concept of noncommunication, which in his own words means that "communicating something under some conditions is undesirable, not because of fear, but because communication would somehow alter the nature of the ideas" (Bateson 1988:80). In his book Mind and Nature Bateson writes that "The letter that you do not write, the apology that you do not offer, the food that you do not put out for the cat - all these can be sufficient and effective messages because zero, in context, can be meaningful; and it is the recipient of the message who creates the context" (Ibid. 56). 
It would also be interesting to study the processes of meaning practices contained in articulation theory in the light of various disciplinary models. Although Claude Lévi-Strauss did not employ the concept of articulation, it (in the sense of linkages) was specifically a question in the analysis of the 'logic of the concrete'. The well-known and in many ways later used core concept of the logic of the concrete was bricolage (Lévi-Strauss 1966), which briefly and concretely means the articulation of perceived similarities or analogies in different entities (things, objects, times).

Folklorists are well aware of the human tendency to structure one's life with the help of personal experiences; cultural models or reflections of social events may, in spite of uniqueness of experiences, guide them. During the course of our lives we describe the same events differently. In addition, different age groups both experience and recall even the same circumstances differently. Alessandro Portelli adds: "Even the same interviewer gets different versions from the same narrator at different times... Historical research with oral sources therefore always has the unfinished nature of a work in progress (1998:71).

Gerard Genette has examined anachronism as a textual form, in fact as a trope, though he does not state this. He reserves "the general term anachrony to designate all forms of discordance between the two temporal orders of story and narrative" (1980:40, 79-85). The main forms are retrospection, or analepsis (the analeptic order of the events a,b,c would be c,b,a), and anticipation, or prolepsis (order of the events $c, a, b)$. Movement in the course of the narrative is therefore not an unintentional error - it can be intentional - but rather the intention is to increase the informational, or at least the narrative, density. Genette also observes "the discordancies between two temporal orders are, however, not entirely limited to analepsis and prolepsis" (Ibid. 40, 48-79).

When anachronism is examined as a trope, like metaphor, metonym, etc., then it is no longer only an error - which it can be - but a consciously chosen means of expression through which relations between the past, present and future are organized. The information in anachronisms changes in accordance with the concept of time (linear, cyclic, structural, and countable) applied. For example, there is a fairy tale of the king's daughter who rejected the marriage her father arranged for her and was sent to a hut in a dark forest to make food for occasional passersby. On the door of the hut was a sign that read "Free today, tomorrow you pay". Today always proceeds tomorrow, so the king's daughter's actual punishment was a timeless existence in which the future never comes.

On the one hand, the trope of anachronism is intertwined with the problematic of free will, where the most debated version is the so-called possibility of doing something differently. Can our own or the whole world's future be affected by doing something 'unexpected'? One of the well known, classic, texts concerning the predestination paradox is Denis Diderot's 1773 novel Jacques le fataliste et son maitre (Jacques the Fatalist and His Master), in which the so-called contrafactual hypothesis, or the consequences of unrealized opportunities, is broadly 
discussed. It is, however, essential that anachronism as a trope is also open to blending into other tropes, especially irony.

Anachronism is also a popular form of comedy. One of the first movies in this sense was Buster Keaton's Three Ages (1923). The film depicts three "boy meets girl who already has a boyfriend" stories set in different eras: cross-cutting between the Stone Age, Ancient Rome and the present, in the past, namely 1920s America. The anachronistic jokes are based on the same episodes articulated with incommensurable time periods: Stone Age baseball and modern traffic problems in ancient Rome.

The Finnish playwright Alexis Kivi wrote the following dialogue between the bridegroom Esko and the matchmaker Mikko in his play Nummisuutarit (1865, The Heath Cobblers). A bit earlier Esko had knocked over a table and broken a window in the wedding hall, and they must now mention this to Esko's mother. They do not want to tell the truth, but lying is not appealing.

Mikko: They'll ask me what happened, and I'll have to tell all, and, sad to say, I'll have to end my tale with your vandal's work at Karri's - yes, Esko, I'll have to mention the overturned table, the smashed windows and violin.

Esko: $\quad$ No need to tell all that, just say we left Karri's a little before I overturned the table.

Mikko: All right, you be your mother and ask me when we left Karri's.

Esko: Mikko Lightfoot, when did you and my boy Esko leave Karri's?

Mikko: We left just before Esko overturned the dinner table.

Esko: Mikko, this is no time for jesting. Say we left just as the wedding guests were leaving for the hayfield.

Mikko: Teach me not to lie.

By manipulating the logic of time or the mutual relations between time series, paradoxical and comic descriptions have been created. The method of describing things which are thought to already exist in the past, though they in reality can only come about in the future, has been called historical inversion, which is a kind of anachronism too. Inversion in time is in fact a goal and by no means a past reality.

\section{Concluding remarks}

I started the current article with some time-travel examples in folklore and science fiction. The aim was to emphasize that the subject of remembering could be both personally experienced and fictional. In any case, it is noteworthy that memory and imagination, which are not the same thing, are articulated together and produce or affirm the actual meanings about the past. This kind of past and present articulation is one of the most important research subjects in contemporary folklore studies. 
In my opinion the combination of memory and narration is always anachronistic in the sense that we are able to remember and tell how the future will come true in the past. However, the interdisciplinary dialogue, discussions and readings remind us that there are also fundamental differences in the disciplinary research traditions, orientation and ways of argumentation. According to Richard Bauman, a prominent American folklorist, "any scholar who is interested in any of the dimensions of interrelationship that link language, literature, culture, society, politics, and history together is potentially my colleague, whatever our degrees and whatever academic departments provide us a home and living" (1996:17). An apt remark, but I must confess, however, that my interdisciplinary enthusiasm collapsed when I attempted to read the article Time Travel and Modern Physics by Frank Arntzenius and Tim Maudlin (2002). I could hardly follow their arguments. I suppose, on the other hand, that they do not have a very congenial attitude to the mythic articulations of time travel stories.

The so-called anachronism debate of recent decades has been concerned with argumentation in academic texts. From the folkloristic point of view it would provide space for new interpretations, the anachronism were seen as a special figure of speech and narrative. Then the focus on interpretation would be on the textual articulation of time, memory, imagination and context, and would open new prospects for understanding how the past is a foreign country.

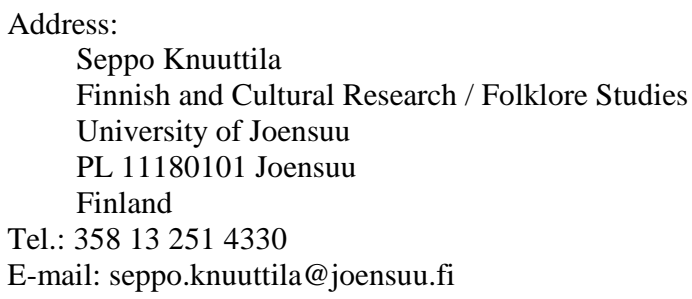

E-mail: seppo.knuuttila@joensuu.fi

\section{References}

Arntzenius, Frank and Tim Maudlin (2002) "Time travel and modern physics". In Time, reality \& experience, 169-200. Craig Callender, ed. (Royal Institute of Philosophy. Supplement, 50.) Cambridge: Cambridge University Press.

Bateson, Gregory (1980) Mind and nature: a necessary unity. London: Flamingo.

Bateson, Gregory and Mary Catherine Bateson (1988) Angels fear: towards an epistemology of the sacred. New York: Bantam Books.

Bauman, Richard (1996) "Folklore as transdisciplinary dialogue." Journal of Folklore Research 33, $1,15-20$.

Di Bari, Marcello and Gouthier, Daniele (2003) "Tropes, science and communication." JCOM: Journal of Science Communication 1 (March). Accessed online in 27.12. 2006 at: http: //jcom.sissa.it/archive/02/01.

Friedrich, Paul (1991) "Polytropy." In Beyond metaphor: the theory of tropes in anthropology, 17-55. James W. Frenandez, ed. Stanford, California: Stanford University Press.

Genette, Gérard (1980 (1972)) Narrative discourse. Basil Blackwell. Oxford. 
Giesen, Bernhard (2004) "Noncontemporaneity, asynchronicity and divided memories." Time \& Society 13, 1, 27-40.

Jaago, Tiiu, Ene Kõresaar, Aigi Rahi-Tamm (2006) "Oral history and life stories as a research area in Estonian history, folkloristics and ethnology." Elore 1/2006. http://cc.joensuu.fi/ loristi/ 1_06/jkr1_06.pdf [Accessed online in 27.12.2006.]

Jardine, Nick (2000) "Uses and abuses of anachronism in the history of the sciences." History of Science 38, 3,121, 251-270.

Kalela, Jorma (2000) Historiantutkimus ja historia. [History Research and History.] Helsinki: Gaudeamus.

Lévi-Strauss,Claude (1966) The savage mind. Chicago: University of Chicago Press

Maguire, Matthew W. (2006) The conversion of imagination: from Pascal through Rousseau to Toquille. (Harvard Historical Studies, 151.) Cambridge, Massachusetts: Harvard University Press.

Mali, Joseph (2003) Mythistory: the making of a modern historiography. Chicago: The University of Chicago Press.

Misztal, Barbara, A. (2003) Theories of social remembering. Philadelphia: Open University Press.

Petterson, Bo (2002) "On the study of imagination and popular imagination: a historical survey and a look ahead." In Popular imagination: essays on fantasy and cultural practice, 11-50. SvenErik Klinkmann, ed. (NNF Publications, 12.) Turku.

Portelli, Alessandro (1998 (1979)) "What makes oral history different?" In The oral history reader, 63-74. Robert Perks and Alistair Thomson ed. Routledge. London and New York.

Reé, Jonathan (1991) “The vanity of historicism.” New Literary History 22, 961-983.

Rehn, Alf (2006) "Anachronism and innovation: a case of hybrid economies in the early 19th century." Management \& Organizational History 22, 1, 71-86

Rosaldo, Renato (1986) "From the door of his tent: the fieldworker and the inquisitor." In Writing culture: the poetics and politics of ethnography, 77-97. James Clifford and George M. Marcus, eds. Berkeley and Los Angeles: University of California Press.

Rorty, Richard (1984) “The historiography of philosophy: four genres." In Philosophy in history. essays on the historiography of philosophy, 49-75. Richard Rorty, J. B. Schneewind, and Quentin Skinner, eds. London and New York: Cambridge University Press.

Sihvola, Juha (2000) “Anakronismi ja sen välttäminen”. [Avoiding Anachronism.] In Jäljillä. Kirjoituksia historian ongelmista. Osa 1, 107-122. Pauli Kettunen, Auli Kultanen, and Timo Soikkanen, eds. Turku: Kirja-Aurora.

Skinner, Quentin (1989) Meaning and understanding in the history of ideas. In Meaning and context - Quentin Skinner and his critics, 26-67. James Tully, ed. Princeton N.J., Princeton University Press.

Schummer, Joachim (2004) "Multidisciplinarity, interdisciplinarity, and patterns of research collaboration in nanoscience and nanotechnology." Scientometrics 59, 3, 425-465.

\section{Sources}

\section{A. Books}

Bradbury, Ray (1962 (1952)) “A sound of thunder”. In Ray Bradbury, ed. $R$ is for rocket. New York: Doubleday.

Diderot, Denis (1999 (1796)) Jacques le fataliste et son maître. Paris : Flammarion.

Kivi, Aleksis (1993 (1864)) The heath cobblers. [In Finnish: Nummisuutarit.] St. Cloud, Mich.: North Star Press of St. Cloud.

Kuznetsov, Boris (1980 (1975)) Putešestvije tšerez epoxi. [A Journey through the Ages.] Moscow: Progress.

Thompson, Stith, ed. (1989 (1932)) Motif-index of folk-literature: a classification ofnNarrative elements in folktales, ballads, myths, fables, mediaeval romances, exempla, fabliaux, jestbooks and local legends. Bloomington \& Indianapolis: Indiana University Press. 


\section{B. Cinematography}

Keaton, Buster (1923) Three ages. Written and directed by Buster Keaton (Edward F. Cline, Clyde Bruckman, Jean C. Havez). Starring: Buster Keaton, Margaret Leahy, Wallace Beery, Lillian Lawrence, Joe Roberts. Cinematography: Elgin Lessley, William C. McGann. US: Metro Pictures. 